\title{
Gentamicin Disposition Kinetics in Humans with Spinal Cord Injury
}

J. L. Segal, M.D., ${ }^{1}$ D. R. Gray, Pharm.D., S. K. Gordon, M.D., I. M. Eltorai, M.D., F. Khonsari, M.D. and J. Patel, Ph.D.

${ }^{1}$ Fellow, American College of Clinical Pharamacology. The Spinal Cord Injury Service and Department of Medicine Veterans Administration Medical Center, Long Beach, California. The California College of Medicine, University of California, Irvine, California, U.S.A.

\section{Summary}

The disposition kinetics of gentamicin, an aminoglycoside antibiotic, were studied in seven tetraplegic and six paraplegic volunteers. The volume of distribution of gentamicin in l/kg of body weight varied in a statistically significant way from values of this parameter measured in normal subjects. The elimination of gentamicin in spinal man proceeded in a log-linear fashion accurately characterized by a one compartment open-model with a half-life of approximately 2 hours.

The clinical significance of altered disposition kinetics and an increased intersubject variability in gentamicin disposition in spinal man as compared to normal subjects is unknown. The existence of these observed differences in pharmacokinetic parameters, however, emphasizes the need to define individual pharmacokinetic profiles and individualize dosing regimens in spinal man. The data presented are supportive of the hypothesis that spinal man constitutes a discreet therapeutic population.

Key words: Tetraplegia; Paraplegia; Gentamicin disposition kinetics; Pharmacokinetics; Spinal man.

\section{Introduction}

In order to establish a rational approach to drug therapy in humans with spinal cord injury (SCI), it is necessary to acquire knowledge of drug metabolism and disposition kinetics in this population. There exists a substantial body of knowledge defining the pathophysiology of SCI in humans (Greenway et al., 1970; Claus-Walker et al., 1977) but essentially no knowledge concerning the extent to which this pathophysiology affects drug disposition kinetics and metabolism in spinal man (Livshits and Yakovlev, 1972; SSIE, 1983).

Gentamicin, an aminoglycoside antibiotic which has its greatest usefulness in the therapy of infections due to gram-negative bacilli, was chosen for pharmaco- 
kinetic analysis because of its wide use in the treatment of sepsis in spinal man. Knowledge of its disposition kinetics in SCI could be expected to have immediate clinical relevance. Low serum protein binding (Gordon et al., 1972), negligible biotransformation (Regamey et al., 1973), and disposition kinetics in the non spinal cord injured accurately characterized by one compartment-open model with first order elimination make it particularly attractive as a study drug (Gyselynck et al., 1971).

This study was implemented to assess the affects of the pathophysiology of SCI on the disposition kinetics of gentamicin after a single intravenous dose.

\section{Materials and methods}

Thirteen male volunteer participants, 20 to 60 years of age, with traumatic spinal cord injury (SCI) receiving gentamicin prophylactically prior to elective urologic surgery and four healthy control subjects with an intact neuraxis were studied. Seven subjects were tetraplegic; six were paraplegic. All SCI subjects had complete physiological spinal cord transection of greater than 1 year duration. Written informed consent was obtained.

Criteria for exclusion from the study were:

1. Acute and/or febrile illness

2. $35 \mathrm{Vol} \% \geqslant$ hematocrit $\geqslant 50 \mathrm{Vol} \%$

3. Cardiac or hepatic disease, renal insufficiency

4. Obesity (body weight $>15 \%$ excess as determined by actuarial tables)

5. Significant high frequency hearing loss

None of the study participants had received or were receiving heparin, aminoglycosides, carbenicillin, or any substances known to alter gentamicin metabolism or interfere with the analytical methodology. All participants pursued unrestricted bedside activities during the sampling period. By studying each volunteer at the same time of day, the possible influence of normal or disrupted circadian rhythms (Claus-Walker et al., 1968) on gentamicin disposition kinetics was kept constant.

Following placement of an indwelling heparinised scalp vein needle, a loading dose of gentamicin $1.5 \mathrm{mg} / \mathrm{kg}$ in 50 c.c. of diluent was infused over 30 minutes into a contralateral extremity. Samples of blood $(5 \mathrm{ml})$ were drawn before beginning the gentamicin infusion, at the end of the infusion (zero time) and at $30,60,90,120,150,180,240,300,360,420$ and 480 minutes. The first 1.5 $\mathrm{ml}$ of each sample of blood was discarded to avoid possible inhibition of gentamicin by the anticoagulant. Serum was separated and stored at $-20^{\circ} \mathrm{C}$ until time of assay. Concentrations of gentamicin were determined by an enzyme immunoassay (O'Leary and Ratcliff, 1980). All samples were run in duplicate with internal standards every 15 samples using a computer directed Gilford 3500 spectrophotometer at $340 \mathrm{~nm}$ and $30^{\circ} \mathrm{C}$.

Following intravenous administration, the elimination kinetics of gentamicin are accurately characterized by a first order process and a one compartment-open model once equilibration has occurred at the end of the distribution phase. Kinetic parameters were derived from analysis of plots of the time-course of log serum gentamicin concentrations obtained from a weighted, iterative, 
nonlinear least-squares regression analysis (Hartley and Booker, 1965; Sawchuk et al., 1977).

Testing for statistical significance of the difference between means and variance of kinetic parameters was carried out using a one-way analysis of variance (ANOVA). The difference between mean values of the serum concentrations of gentamicin vs time in quadriplegic and paraplegic subjects was evaluated for statistical significance using a two way split-plot ANOVA (Kirk, 1982). Statistical analysis of data was carried out on a HP-85 microcomputer.

\section{Results}

Pharmacokinetic parameters for gentamicin in spinal man are displayed in Table 1. The mean volume of distribution of gentamicin expressed in $1 / \mathrm{kg}$ of body weight ( $\mathrm{gVd}$ ) was greater in spinal man (tetraplegic plus paraplegic subjects) as compared to an experimentally determined mean for normal volunteers. This difference was statistically significant $(p<0.05)$. The mean Vd gentamicin in paraplegic subjects was greater than the mean $\mathrm{Vd}$ gentamicin in tetraplegic subjects or controls. Statistical significance for this observed difference was not demonstrated. The difference between the variances of $\mathrm{gVd}$ in tetraplegic subjects and in tetraplegic plus paraplegic subjects (spinal man) as compared to controls was statistically significant (Table 1 ).

Two-variable correlation analysis of $\mathrm{gVd}$ with age of subject, level of injury and time elapsed since injury in all subjects, tetraplegic subjects, or paraplegic subjects demonstrated no statistically significant associations.

The mean total clearance of gentamicin $\left(\mathrm{gCl}_{\mathrm{T}}\right)$ in $\mathrm{ml} / \mathrm{kg} / \mathrm{min}$ was greater in spinal man (tetraplegic plus paraplegic subjects) but this difference was not statistically significant as compared to an experimentally obtained mean for volunteers with an intact neuraxis. Difference between the variances of $\mathrm{gCl}_{\mathrm{T}}$ in tetraplegic subjects, paraplegic subjects and controls was not statistically significant (Table 1 ). Values for $\mathrm{gCl}_{\mathrm{T}}$ in tetraplegic subjects and paraplegic subjects demonstrated wide intersubject variability.

Two-variable correlation analysis of $\mathrm{gCl}_{\mathrm{T}}$ with age of subject, level of injury and time elapsed since injury in all subjects, tetraplegic subjects or paraplegic subjects demonstrated no statistically significant associations.

Analysis of plots of log serum gentamicin concentration vs time in tetraplegic subjects, paraplegic subjects, and tetraplegic plus paraplegic subjects showed similar elimination patterns after the distribution phase (Figs. 1 and 2). Apparent differences between the means of serum gentamicin concentrations in tetraplegic and paraplegic subjects over time did not reach statistical significance (Fig. 2). Extensive intersubject variability of pharmacokinetic parameters was observed in spinal cord injured subjects (Fig. 3). The mean elimination half-life $\left(t \frac{1}{2}\right)$ gentamicin for all study subjects and sub-groups did not differ significantly from the experimentally derived gentamicin elimination half-life $\left(t \frac{1}{2}\right)$ in normal subjects which correlated well with literature values (Table 1).

\section{Discussion}

The pathophysiology of spinal cord injury (SCI) in the acute and chronic phase 
Table 1 Pharmacokinetics of Gentamicin in patients with spinal cord injury

\begin{tabular}{|c|c|c|c|c|c|c|c|c|c|}
\hline & & & & Volume & Distribution ${ }^{\mathrm{b}}$ & & & & \\
\hline Patient & $\begin{array}{l}\text { Gentamicin } \\
\text { Dose (mg) }\end{array}$ & $\begin{array}{c}1\left(\mathrm{hr}^{-1}\right) \\
\mathrm{Kel}^{-1}\end{array}$ & $\begin{array}{c}\text { Half-Life } \\
\text { (hours) }\end{array}$ & Litres (1) & $\begin{array}{c}\text { 1/kg Total } \\
\text { Body Weight }\end{array}$ & & ANOVA & $\begin{array}{c}\text { Clearance }^{\mathrm{b}} \\
(\mathrm{ml} / \mathrm{kg} / \mathrm{min})\end{array}$ & ANOVA \\
\hline Tetraplegic & & & & & & & & & \\
\hline 1 & $119 \cdot 0$ & $0 \cdot 271$ & $2 \cdot 6$ & $25 \cdot 1$ & 0.32 & & 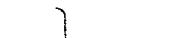 & 1.43 & \\
\hline 2 & $122 \cdot 0$ & $0 \cdot 287$ & $2 \cdot 4$ & $22 \cdot 2$ & $0 \cdot 27$ & & & $1 \cdot 31$ & \\
\hline 3 & $120 \cdot 0$ & 0.301 & $2 \cdot 3$ & $24 \cdot 6$ & 0.31 & & & 1.55 & \\
\hline 4 & $98 \cdot 0$ & 0.476 & 1.5 & $21 \cdot 3$ & 0.33 & $P<0.05$ & & 2.50 & \\
\hline 5 & $125 \cdot 0$ & 0.357 & 1.9 & $35 \cdot 0$ & $0 \cdot 47$ & & & $2 \cdot 78$ & \\
\hline 6 & 113.0 & $0 \cdot 277$ & 2.5 & $36 \cdot 3$ & $0 \cdot 48$ & & & $2 \cdot 23$ & \\
\hline 7 & 153.0 & 0.292 & $2 \cdot 4$ & $34 \cdot 4$ & 0.34 & & & 1.63 & \\
\hline Mean $\pm S D$ & $121 \pm 17$ & $0.323 \pm 0.07$ & $2 \cdot 2 \pm 0.4$ & $28 \cdot 4 \pm 6 \cdot 5$ & $0.36 \pm 0.08$ & & $F=9$ & $1.91 \pm 0.58$ & \\
\hline controls & $106 \pm 14$ & $0.341 \pm 0.03$ & $2 \cdot 1 \pm 0 \cdot 1$ & $17 \cdot 9 \pm 1 \cdot 3$ & $0 \cdot 26 \pm 0.02$ & & $P<0.05$ & $1.46 \pm 0.08$ & \\
\hline Paraplegic & & & & & & & & & NS \\
\hline 8 & $106 \cdot 0$ & 0.436 & $1 \cdot 6$ & $32 \cdot 4$ & $0 \cdot 46$ & & & 3.35 & \\
\hline 9 & $75 \cdot 0$ & 0.558 & $1 \cdot 2$ & $27 \cdot 0$ & 0.54 & & & 5.02 & \\
\hline 10 & $91 \cdot 0$ & $0 \cdot 278$ & $2 \cdot 5$ & $23 \cdot 7$ & 0.39 & & & 1.82 & \\
\hline 11 & $137 \cdot 0$ & $0 \cdot 252$ & $2 \cdot 7$ & $23 \cdot 1$ & $0 \cdot 25$ & NS & & 1.07 & \\
\hline 12 & 143.0 & $0 \cdot 260$ & $2 \cdot 7$ & $25 \cdot 0$ & $0 \cdot 26$ & & & $1 \cdot 14$ & \\
\hline 13 & $85 \cdot 0$ & 0.257 & $2 \cdot 7$ & $19 \cdot 0$ & 0.33 & & & 1.43 & \\
\hline Mean \pm SD & $106 \pm 28$ & $0.340 \pm 0.13$ & $2 \cdot 2 \pm 0 \cdot 7$ & $25 \cdot 0 \pm 4 \cdot 5$ & $0.37 \pm 0.11$ & & & $2.31 \pm 1.6$ & \\
\hline All Patients & $114 \pm 23$ & $0.331 \pm 0.10$ & $2.2 \pm 0.5$ & $26 \cdot 9 \pm 5 \cdot 7$ & $0.37 \pm 0.09$ & & & $2 \cdot 10 \pm 1 \cdot 1$ & \\
\hline controls & $106 \pm 14$ & $0.341 \pm 0.03$ & $2 \cdot 1 \pm 0 \cdot 1$ & $17 \cdot 9 \pm 1 \cdot 3$ & $0.26 \pm 0.02$ & & & $1.46 \pm 0.08$ & \\
\hline Literature Value & & & $2-3^{a}$ & & $0.25 \pm 0.05^{a}$ & & & ${ }^{\mathrm{a}} 1 \cdot 20 \pm 0 \cdot 26^{\mathrm{a}}$ & \\
\hline
\end{tabular}

'Derived from Goodman and Gilman's The Pharmacological Basis of Therapeutics, 6th Edition, 1980.

b A statistically significant different $(p<0.05)$ in the volume of distribution of gentamicin was demonstrated by analysis of variance (ANOVA) in tetraplegic subjects and in tetraplegic plus paraplegic subjects (spinal man) as compared to controls. 


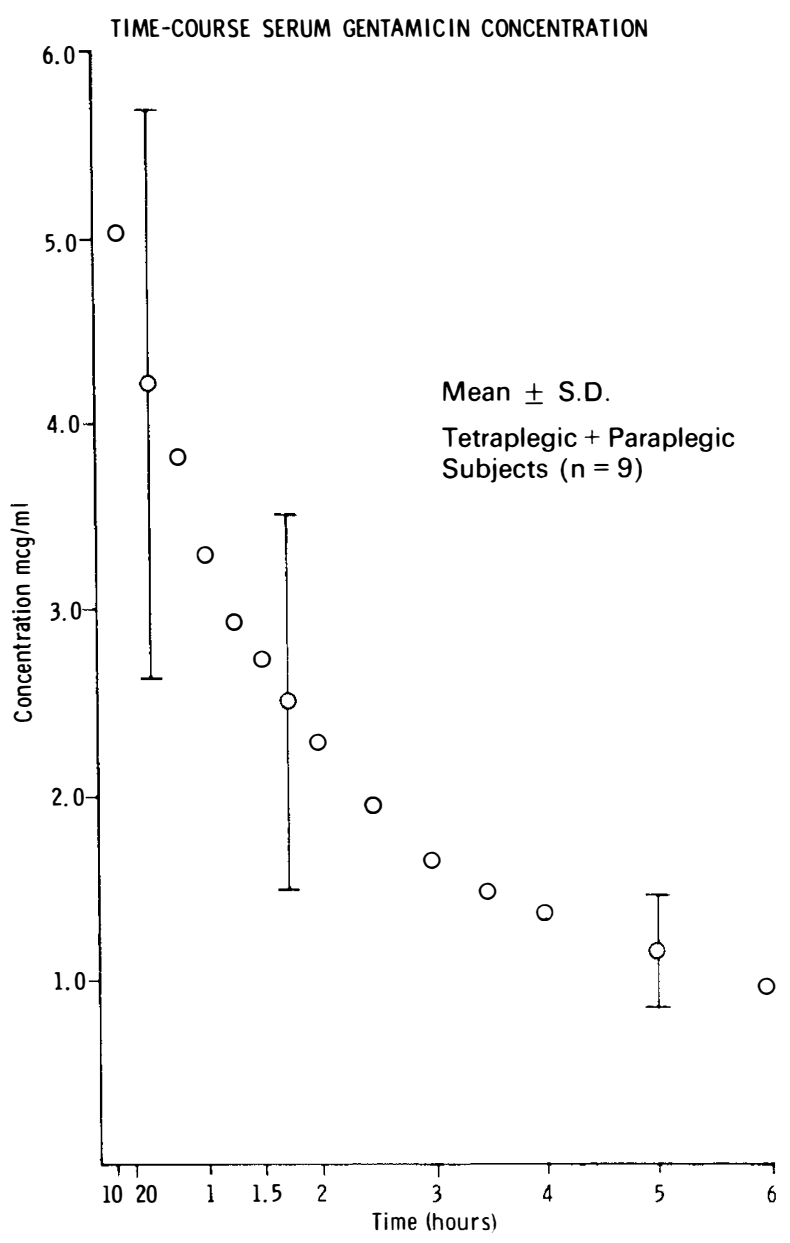

Figure 1. Decline of serum gentamicin levels in spinal man (aggregate data) following a 30-minute intravenous infusion of $1.5 \mathrm{mg} / \mathrm{kg}$ total body weight.

is extensive (Mathias et al., Desmond, 1970). Using gentamicin, an aminoglycoside antibiotic with a well studied pharmacokinetic profile, a protocol was designed to test the hypothesis that the pathophysiology of spinal cord injury alters the disposition kinetics of drugs.

Analysis of the time-course of serum gentamicin levels in spinal man resulted in the calculation of values for pharmacokinetic parameters, which differed in a statistically significant way from experimentally derived values in normal subjects. Greater intersubject variability in pharmacokinetic parameters found in spinal man as compared to normal subjects. The greatest intersubject variability in pharmacokinetic parameters, contrary to expectations, was observed in the paraplegic subjects and many reflect the wider, more varied spectrum of physiologic disruption in this population and the resultant diversity of pathology to be expected in this the neurophysiologically least homogeneous of all study groups. 


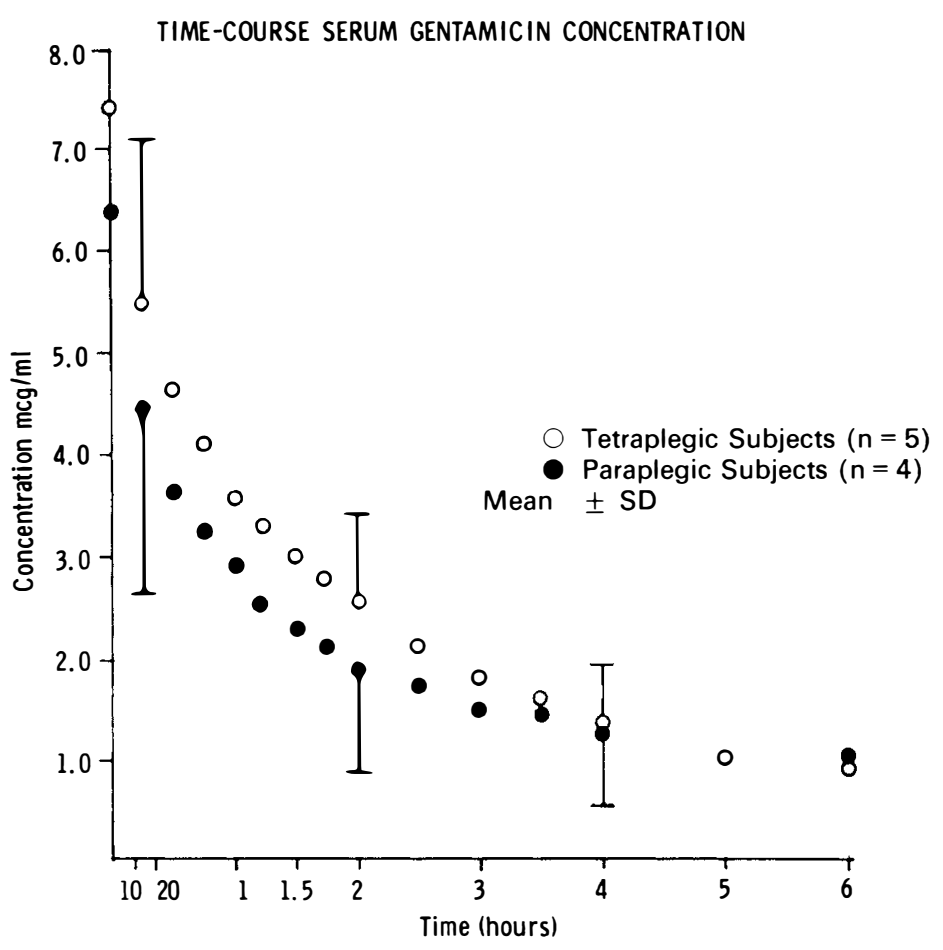

Figure 2. Decline of serum gentamicin levels in tetraplegic subjects $(\bigcirc)$ as compared to paraplegic subjects $(0)$ following a 30 -minute intravenous infusion of $1.5 \mathrm{mg} / \mathrm{kg}$ total body weight. The difference between the means of serum gentamicin levels at each time in tetraplegic subjects as compred to paraplegic subjects did not reach statistical significance.

The observed increase in the volume of distribution of gentamicin in $1 / \mathrm{kg}$ of total body weight in spinal man as compared to normal subjects may be attributed to an absolute increase in extracellular fluid volume. This may be due to extensive erosion of muscle mass and other factors such as diminished peripheral venomotor tone contributing to the formation of subclinical oedema (Greenway et al., 1970; Bidart et al., 1971). The ratio of body fat to total body weight increases both in spinal man and in normals with ageing. These changes are seen earlier and are of a greater magnitude in spinal man suggesting that these changes are dependent on the pathophysiology of SCI and not the physiological changes which normally accompany ageing, chronic illness or extended immobilization (Greenway et al., 1970).

The apparent volume of distribution of gentamicin is approximately 25 per cent of total body weight and corresponds to extracellular fluid volume (Ristuccia and Cunha, 1982). No statistically significant difference in the volume of distribution of gentamicin in $1 / \mathrm{kg}$ of total body weight $(\mathrm{gVd})$ was observed in paraplegic subjects as compared to tetraplegic subjects. Since a significant distribution of gentamicin to adipose tissue has been demonstrated in normal subjects (Schwartz et al., 1978), a greater $\mathrm{gVd}$ might be expected in tetraplegic subjects. Our data, however, contradict this and suggest that additional factors unique to the pathophysiology of SCI are operative. Among these are disturbances of cate- 

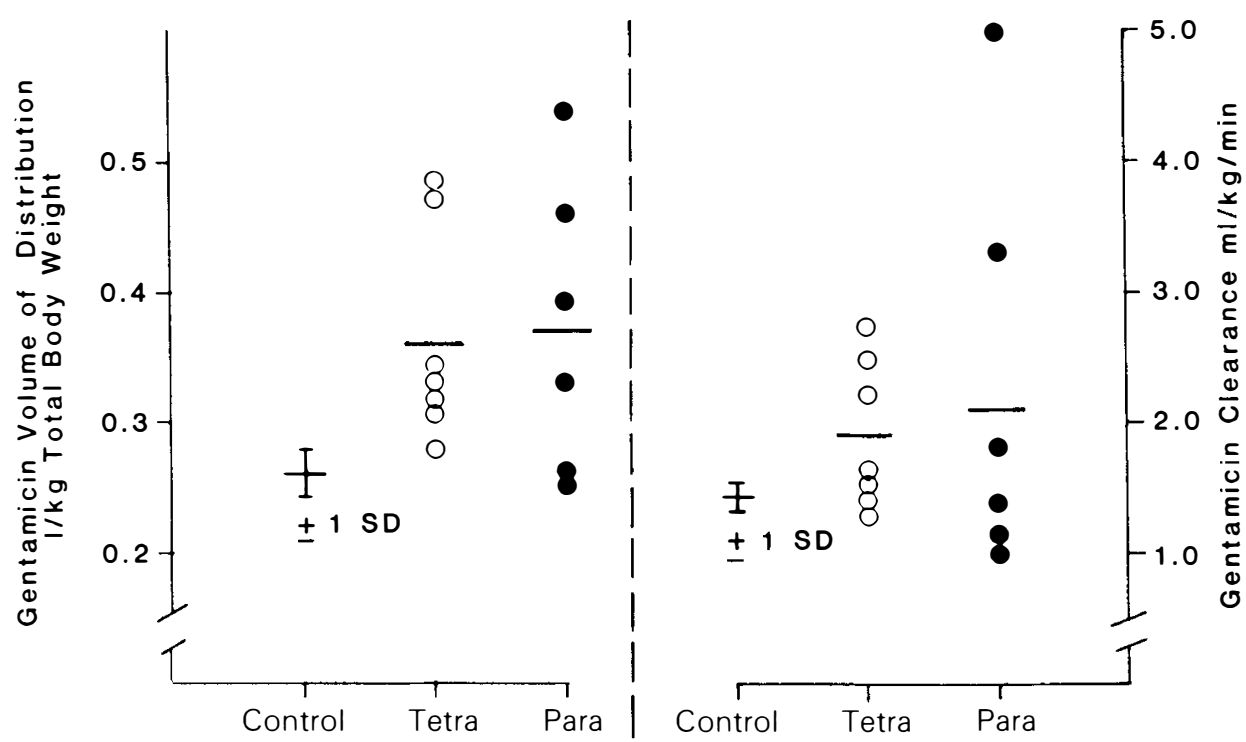

Figure 3. Total body clearance andvolume of distribution of gentamicin in spinal cord injured subjects and controls are compared. Marked intersubject variation of these parameters is seen in spinal cord injured subjects with the greatest variance demonstrated in paraplegic subjects $(O)$ as compared to tetraplegic subjects $(\mathbf{)})$ and controls.

cholamine metabolism which result in changes in systemic vascular resistance in spinal man and serve to further distinguish paraplegic from tetraplegic subjects (Naftchi et al., 1972). These alterations in catecholamine metabolism may be implicated as factors contributing to a redistribution of extracellular fluid volume measurable as a change in the apparent volume of distribution of gentamicin. In the aggregate, these disturbances of gross body composition, venomotor tone and systemic vascular resistance explain the change in volume of distribution which appears to distinguish spinal man from normal subjects.

Total body clearance of gentamicin was greater in spinal cord injured subjects than in subjects with an intact neuraxis, however, a statistically significant difference between means was not demonstrated and our data allows us to conclude that an increase in the volume of distribution of gentamicin is the major determinant of gentamicin disposition in spinal man.

Following a single 30 -minute intravenous infusion of gentamicin $1.5 \mathrm{mg} / \mathrm{kg}$, serum levels remained above $1.0 \mu \mathrm{g} / \mathrm{ml}$ for less than 5 hours in more than 75 per cent of spinal cord injured subjects during the 8-hour study period. This observation suggests a significant potential for under-dosing this population with a resultant decrease in the therapeutic efficacy of gentamicin, if the clinician initiates therapy using algorithms or dosing regimens based on pharmacokinetic data obtained from the study of humans with an intact neuraxis.

The clinical significance of altered disposition kinetics of gentamicin in spinal man is unknown. The intersubject variability in gentamicin disposition and the uncertainty in predicting individual kinetic parameters emphasize the need to define individual pharmacokinetic profiles and individualize gentamicin dosing 
regimens (Sawchuck et al., 1977). This need to individualize gentamicin dosing regimens in spinal man may ultimately be shown to include other drugs which share a pharmacokinetic profile with gentamicin.

The limited data are supportive of the hypothesis that spinal man constitutes a discreet population defined by characteristic pharmacokinetic parameters. Much work remains to be done, however, in order to understand and better characterize the clinical significance of altered gentamicin disposition kinetic in spinal cord injury.

\title{
Acknowledgements
}

This investigation was supported in part by Beacham Laboratories, the Veteran's Assistance League, LBVAMC and the California Paralyzed Veterans Association: We thank Dr Richard A. Charter for technical assistance.

\begin{abstract}
Résumé
La cinétique de la disposition de la gentamicine, un antibiotique de la catégorie des aminoglycosides, fut étudiée chez 7 tétraplégiques et 6 paraplégiques, tous volontaires. Le volume de distribution de la gentamicine différe d'une facon statistiquement significative chez ces patients, d'avec les données obtenues pour ce paramètre chez les sujets normaux. L'élimination de la gentamicine chez l'humain myélopathique ('spinal') se fit selon un mode logarithmique linéaire, caracterisé avec précision par un modèle ouvert à compartiment unique, avec une demi-vie d'environ deux heures.

La portée clinique de l'altération de la cinétique de disposition chez le myélopathique, et de la variabilitié augmentée d'un sujet à l'autre, dans la disposition de la gentamicine, chez ce patient, n'est pas connue.

Toutefois, le fait de l'existence de ces différences dans les paramètres pharmacocinétiques concernant la gentamicine met en relief le besoin de définir des profils pharmacocinétiques individualisés, comme le seront les régimes de dosages, chez le sujet myélopathique. Les données présentées supportent l'hypothèse selon laquelle ce dernier fait partie d'une population unique sur le plan thérapeutique.
\end{abstract}

\section{Zusammenfassung}

Die Dispositionskinetik von Gentamycin, ein Aminoglykosid antibiotik, wurden in 7 freiwilligen Quadriplegie und 6 Paraplegie Patienten studiert. Die verteilungsvolumen von Gentamycin, berechnet als Prozentasatz des Koerpergewichts, variert in einer statistich bedeutsamen Weise von denen des normalen Menschen. Die Ausscheidung von Gentamycin in Rueckenmark verlaetzten Patienten schaut in der log-linear Form genauso aus wie ein ein-Abteiliges offener Modell mit einem Halb-leben von ungefaehr zwei stunden.

Die klinische Bedeutung von einer veraenderten Dispositionskinetik und einer erhoehten zwischen Patienten differenz in Gentamycin disposition in Rueckenmark verlaetzten Patienten, verglichen mit normalen Menschen, ist unbekannt. Diese Beobachtungen von verschieden pharmacokinetischen Parametern betonen das Beduerfnis individuell pharmacokinetische Profile und einzelne Dosregimente in Reukenmark verlaetzten Patienten festzusetzen. Die dargestellten Angaben unterstuetzen diese Hypothese und zeigen dass Rueckenmark verlaetzte Patienten eine einzige therapeutische Bevoelkerung ausmachen.

\section{References}

BIDART Y, DURAND J 1971 The nervous control of peripheral venous constriction at the beginning of exercise. A comparative study in normal man and in paraplegia due to section of the spinal cord. Pathologie biologie (Paris) 19:13-19

Claus-Walker J, Carter RE et al. 1977 Immediate endocrine and metabolic consequences of traumatic quadriplegia in a young woman. Paraplegia 15:202-208.

Claus-Walker JL, CARTER RE et al. 1968 Analysis of daily rhythms of adrenal function in men with quadriplegia due to spinal cord section. Paraplegia 69:195-207. 
DESMOND J 1970 Paraplegia: Problems confronting the anaesthesiologist. Canadian Anaesthetists Society Journal 17:435-451.

GORDON RC, REGAMEY C et al. 1972 Serum protein binding of aminoglycoside antibiotics. Antimicrobial Agents and Chemotherapy, 2:214-216.

GREENWAY RM, HOUSER HB et al. 1970 Long term changes in gross body composition of paraplegic and quadriplegic patients. Paraplegia 7:301-308.

GYSELYNCK AM, FORREY A et al. 1971 Pharmacokinetics of gentamicin: distribution and plasma and renal clearance. Journal of Infectious Diseases 124:6570-576.

HARTLEY HO, BOOKER A 1965 Non-linear least squres estimation. Ann. Math. Stat. 36: 638-650.

KIRK RE 1982 Experimental Design, 2nd ed., Brooks/Cole Publ.

Livshits AV, YAKOvLEv VP 1972 Dynamics of doxycycline levels in cases with trauma of the spinal marrow. Antibiotki. 17:844-847.

MAthias CJ, Christensen NJ et al. 1979 Cardiovascular control in recently injured tetraplegics in spinal chock. Quarterly Joumal of Medicine, New Series XLVIII 190:273-287.

Naftchi NE, Lowman BW et al. 1972 Peripheral circulation and catecholamine metabolism in paraplegia and quadriplegia. Archives of Physical Medicine 53:357-361.

O'LEARY TD, RATCLIFF RM 1980 Evaluation of an enzyme immunoassay for serum gentamicin. Antimicrobial Agents and Chemotherapy 17:776-778.

REGAMEY C, GORDON RC et al. 1973 Comparative pharmacokinetics of tobramycin and gentamicin. Clinical Pharmacology and Therapeutics 14:396-403.

RistuCCIA AM, CUNHA BA 1982 The aminoglycosides (symposium on antimicrobial therapy). Medical Clinis of North America 66:303-312.

SAWCHUK RV, ZASKE DE et al. 1977 Kinetic models for gentamicin dosing with the use of individual patient parameters. Clinial Pharmacology and Therapeutics 21:362-369.

SchWARTZ SN, PAZIN GJ et al. 1978 A controlled investigation of the pharmacokinetics of gentamicin and tobramycin in obese subjects. Journal of Infectious Diseases 4:499-505.

SmithSONIAN SCIENCE INFORMation ExChange (SSIE) 1983. 